\title{
Characteristics of the mythological image of wild animals in the oral folk arts of altaians
}

\author{
DOI: 10.31551/2410-2725-2019-5-3-390-405
}

\section{Muytueva Irina Nikolaevna}

candidate of Pedagogical Sciences, senior Researcher of Research Institute of Altaistika named after S.S. Surazakov, Russian Federation, Altai Republic, Gorno-Altaisk. E-mail: muytuevai@mail.ru

\begin{abstract}
Annotation: The study of images of the animal world helps to study the religious beliefs, prospects and trends in the development of the spiritual culture of the people. The functionality of images is connected, first of all, with the division of the world into two beginnings, although it is impossible to unequivocally talk about this, since many of the images have a dual position in the dualistic picture of the world. The dualistic cosmogonic myth of the creation of the world by two gods is the basis of the entire universe of Altaians and plays such a fundamental role that it can be defined as a narrative that structures not only the traditional religious and mythological picture, but also the entire spiritual culture of society. The dualism of the cosmogonic myth in the traditional picture of the world is present everywhere, in the creation and structure of the earth, man, animal world, flora, respectively, ceremonies and customs associated with it are subject to it. For completeness of coverage of the studied topic, isolated information was collected from various sources about the remnants of the animal cult of the Altai people. We are far from the fact that in this study we illuminated the mythological images of wild animals in all its manifestations in the Altaian myth-ritual tradition, but this is the beginning. Separate motifs of animal worship in the oral folklore of the Altaians could have been formed under the influence of fear of some animal or the result of the deification of certain animals. But today, it is almost impossible to single out one or another reason for worshiping individual animals, since we fix their already established cult images. A comprehensive study of the mythological images of the animal world in Altai folkloristics remains relevant.
\end{abstract}

Keywords: image; fauna; dualism; oral folk art; totem; bear; wolf; hare, woodchuck.

\section{Алтайлықтардың халық ауыз шығармашылығындағы жабайы жануарлардың аңыздық бейнелерінің сипаттамасы}

\section{Муйтуева Ирина Николаевна}

педагогика ғылымдарының кандидаты, С.С. Суразаков атындағы алтаистика ғылыми-зерттеу институтының аға ғылыми қызметкері, Ресей Федерациясы, Алтай Республикасы, ГорноАлтайск қ. E-mail: muytuevai@mail.ru

Аңдатпа: Жануарлар әлемінің бейнесін зерттеу халықтың діни сенімін зерттеуге ықпал етіп, рухани мәдениетінің болашағы мен даму тенденциясын анықтауға мүмкіндік береді. Бейнелердің функционалдылығы ең алдымен, әлемді екі бастауға бөлумен байланысты. Бірақ ол туралы бір жақты айтуға болмайды, себебі, көптеген образдар әлемнің дуальды бейнесінде екі жақты мағынада болады. Әлемді екі құдай жаратты деген дуалистік космогониялық аңыз, алтайлықтардың дүниетанымының негізі болып, қоғамның тек дәстүрлі діни - мифологиялық картинасының құрамдас бөлігін сипаттаушы ғана емес, сонымен қатар, қоғамның бүкіл рухани мәдениетінің іргетасы болып табылады. Әлемнің дәстүрлі бейнесінде космогониялық аңыз дуализмі жер, адам, жануарлар әлемі, өсімдіктер әлемінің пайда болуы мен құрылымы туралы түсініктердің барлығында кездеседі, сондықтан, онымен байланысты әдет - ғұрыптар соған бағынышты болады. Осы тақырыпты толығымен зерттеу үшін алтайлықтардың жануарларға табынуы туралы әртүрлі деректерден мәліметтер жиналған. Бұл зерттеу жұмысында алтайлықтардың мифоғұрыптық дәстүрлеріндегі жабайы жануарлардың мифологиялық бейнелерін барлық жағынан қарастырған. Алтайлықтардың халық ауыз шығармашылығында жануарларға табынудың жеке көріністері олардың қандай да бір жануардың алдындағы қорқыныштан немесе кейбіреулеріне құдайлық табынудың әсерінен болуы мүмкін. Бірақ бүгінгі күні жеке жануарларға табыну себептерін анықтау мүмкін емес, себебі, біз олардың қалыптасқан ғұрыптық бейнесін көрсетеміз. Алтай фольклорында жануарлар дүниесінің мифологиялық бейнесін кешенді зерттеу өзекті болып табылады.

Түйін сөздер: бейне, жануарлар әлемі; дуализм; халық ауыз шығармашылығы; тотем; аю; қасқыр; қоян; суыр. 


\title{
Характеристика мифологического образа диких животных в устном народном творчестве алтайцев
}

\author{
Муйтуева Ирина Николаевна \\ кандидат педагогических наук, старший научный сотрудник Научно-исследовательского \\ института алтаистики им С.С.Суразакова, Российская Федерация, Республика Алтай, Горно- \\ Алтайск. E-mail: muytuevai@mail.ru
}

\begin{abstract}
Аннотация: Исследование образов животного мира помогает изучить религиозные верования, перспективы и тенденции развития духовной культуры народа. Функциональность образов связана, прежде всего, с делением мира на два начала, хотя однозначно говорить об этом нельзя, так как у многих образов двоякое положение в дуальной картине мира. Дуалистический космогонический мифр о создании мира двумя богами является основой всего мироздания алтайцев и играет настолько фундаментальную роль, что его можно определить, как повествование, структурирующее не только традиционную религиозно-мифологическую картину, но и всю духовную культуру общества. Дуализм космогонического мифа в традиционной картине мира присутствует повсюду, в создании и структуре земли, человека, животного мира, растительного мира, соответственно обряды, обычаи, связанные с ним, подчинены ему. Для полноты освещения исследуемой темы были собраны разрозненные сведения из разных источников о пережитках культа животных у алтайцев. Мы далеки от того, что в данном исследовании осветили мифологические образы диких животных во всех проявлениях в мифоритуальной традиции алтайцев, но это начало. Отдельные мотивы преклонения перед животными в устном народном творчестве алтайцев могли складываться под воздействием страха перед каким-то животным или следствием обожествления тех или иных животных. Но сегодня выделить те или иные причины преклонения перед отдельными животными почти невозможно, так как мы фиксируем уже сложившиеся их культовые образы. Комплексное изучение мифологических образов животного мира в алтайской фрольклористике остается актуальным.
\end{abstract}

Ключевые слова: образ; животный мир; дуализм; устное народное творчество; тотем; медведь; волк; заяц; сурок.

\section{УДК/UDC 398.3}

\section{Характеристика мифологического образа диких животных в устном народном творчестве алтайцев}

\section{И.Н. Муйтуева}

Введение. У алтайцев с древнейших времен существует очень богатое устное народное творчество. Культ животных у алтайцев сложился в религиозную систему на ранних этапах формирования и развития этноса. Именно в мифах, преданиях, сказках, героических преданиях отражены образы животных, которые имеют очень глубокие корни. Мир животных в первобытном сознании прочно соединен с миром первопредков. У алтайцев это время связывается с «временем творения», с тем временем, когда создавались природа и общество. Основные поверья этноса можно определить, как более развитую форму культа животных - тотемизм (букв. - поклонение зверям). Мифы о тотемных предках говорят, о происхождении людей, родов, животных и т.д. Алтайцы всегда относились с почитанием и уважительным отношением к природе, это отношение выражается в традиционной культуре, нравах и обычаях. Фольклор народа всегда относится к той части культурных ценностей, которая никогда не теряет своей актуальности и значимости. Любые тексты устного народного творчества всегда вызывают живой интерес в изучении культуры народа. 
Человек постигал мир, воспринимая его в многообразии и целостности. Разнообразные животные существовали на земле вместе с человеком, всегда окружали его и играли большую роль в жизни общества. Издревле человек наблюдал их повадки, которые говорили о том, что животные тоже наделены умом и характером, складывалось представление о том, что животные - тоже «люди»: они могут разговаривать друг с другом, понимать, ходить на охоту. Поэтому в фольклорных произведениях звери и люди на равных ведут общение, могут жить вместе, ходить в гости и помогать друг другу.

Актуальность выбранной темы состоит в том, что в данном исследовании делается попытка на базе разнообразного круга источников комплексно осветить вопрос о месте и роли диких животных в устном народном творчестве алтайцев. Восстановить смысл и содержание описываемых явлений, выявить наиболее древние элементы традиционного мировоззрения алтайцев в преклонении перед животными.

Необходимость изучения мифологического образа диких животных состоит в том, что подобный ракурс позволяет в относительной мере осветить структуру архаического мировоззрения алтайцев, отраженного в устном народном творчестве. Исследование образов мира природы помогает изучать религиозные верования, перспективы и тенденции развития духовной культуры народа. Функциональность образов связана, прежде всего, с делением мира на два начала, хотя однозначно говорить об этом нельзя, так как у многих образов, как например, у медведя и волка предполагается двоякое положение в дуальной картине мира.

Материалы и методы. Методологическую основу исследования составили принцип аналитического, сравнительно-исторического анализа фольклорных, литературных, этнографических, лингвистических источников.

Обсуждение. Академик В.В. Радлов в середине XIX в. путешествовал по Алтаю и собрал богатейший фольклорный материал, который издал в книге «Образцы народной литературы тюркских племен, живущих в Южной Сибири и Дзунгарской степи» в I части. В данной книге мы находим сказки: «Хвастовство зайца» (Койоноктынмактанганы), «Плачь сороки» (Санысканнынсыгыды), «Лягушка» (Пака), «Журавль и лиса» (Турнабыла тӱлкӱчек), «Собака с голодными глазами» (Ачкӧстӱийт), в которых образы животных характеризуют людей, осмеиваются их недостатки. Вслед за В.В. Радловым начал собирать сказки и предания народов Южной Сибири и Западной Монголии Г.Н. Потанин, которые издал в книге «Очерки Северо-Западной Монголии». Алтайский материал был опубликован в четвёртом выпуске. В.И. Вербицкий издал книгу «Алтайские инородцы», куда вошли песни, пословицы, поверья, загадки, и сказки, образцы текстов даны в пересказе на русском языке. В начале XX в. алтайский фольклор собирал Н.Я. Никифоров и издал их в книге «Аносский сборник».

Специальных работ по символике животного мира у алтайцев нет. Исследователи касались данной темы в той или иной степени во время изучения традиционной культуры, устного народного творчества. Работы Е.М. Мелетинского, Р.С. Липец, В.Я. Проппа, В.М. Жирмунского - освещают общетеоретические вопросы фрольклористики и мифрологии тюркских народов, в том числе, алтайцев.

В начале XX в. знаменитый алтайский художник Г.И. Чорос-Гуркин собирал предания, сказки и этнографический материал алтайцев, которые были изданы отдельным сборником «Алтайские сказки», совместно с писателем Г.Ч. Вяткиным. 
В 1930-1940 годах активным собирателем алтайского фольклора был П.В.Кучияк. Сказки, собранные П.В. Кучияком, были обработаны и переведены на русский язык А.Л. Гарф. Они вышли в книге «Сказки Алтая» «Сартакпай».

В 1945 г. издаются сказки Ч.А. Чунижекова «Детские сказки» (Балдардынчӧрчӧктӧри), где выходят по нашей теме сказки «Лиса и сеноставка» (Тӱлкӱнеклесыгырган), «Сирота, медведь и лиса» (Ӧскӱзек, айулатӱлкӱ), «Пять братьев» (Бешкарындаш), «Мужик и лиса» (Ӧбӧӧнлӧтӱлкӱ), «Драгоценность» (Эрјине).

В 40-е годы XX века сбором фрольклорного и лингвистического материала занимался Н.А. Баскаков, он изучил языковые различия диалектов алтайского языка, и издал 1948 году книгу «Алтайский фольклор и литература», где дал классификацию устного народного творчества алтайцев.

В 1952 году создается научно-исследовательский институт истории, языка и литературы, где под руководством фольклориста С.С. Суразакова начинается развернутое целенаправленное собирание материалов по всем жанрам фольклора. Выходят работы ученых фрольклористов 3.С. Казагачевой, С.С.Каташа, Е.Е. Ямаевой, К.Е. Укачиной, М.А. Демчиновой, Т.М. Садаловой, А.А. Конунова, К.В. Ядановой и других исследователей.

Специального исследования, посвященного раскрытию символики мифрологического образа диких животных в алтайском устном народном творчестве, пока нет. Фрагментарно о животных упоминают в своих работах С.С. Суразаков «Алтай фольклор» (1975), В.А. Муйтуева «Традиционная религиозно-мифологическая картина мира» (2004), В.П. Ойношев «Система мифологических символов в алтайском героическом эпосе» (2006).

Результаты. Дуализм лежит в основе создания животного и растительного мира алтайцев. Алтайцы точно знают, какое дерево или животное каким божеством создано, и как к нему относиться.

Каждый род (сӧӧк) алтайцев имеет своего первопредка - почитаемого животного или птицу. Они покровительствуют и берегут род от злых духов и всевозможных опасностей. Нельзя было убивать почитаемого животного. Поэтому каждый человек с особым почтением и уважением относится к животному или птице своего рода. Зооморфизм, космогония, художественный вымысел, вера в сверхъестественное - все переплетено в мифрологии. Видимо, обожествление тотема сложилось, когда людям надо было объяснить суть кровного родства. Тогда же и появились мифы о чудесных поступках птиц и зверей. Повествования о животных заставляют задуматься над нормами человеческого поведения. В мифах многих народов животные дают людям разные блага, учат обычаям и обрядам, в них прослеживается установка на познание мира животных. Для изучения древних образов и символов чрезвычайно важным источником является устное народное творчество: мифы, сказки, легенды, эпос, песни, а также обычаи, обряды и ритуалы, наскальные рисунки, сохранившиеся на территории Алтая. Они не только драгоценные свидетельства культуры, мышления, восприятия и мировоззрения алтайцев, но и являются источниками исторических исследований. В народной культуре не может быть ничего произвольного. Каждый символ, образ фольклора, обряда отточены веками работы общественного сознания. В образах зверей люди видели своих прародителей, они эстетизировались и несли в себе глубокий символический смысл. Зооморфные образы также несли в себе глубокий символический смысл. Об этом свидетельствуют выбитые на камнях изображения. К сожалению, природные процессы не позволили всем произведениям искусства 
сохраниться до современности. Нанесение рисунков животных на камни давало надежду и на покровительство духа-хозяина, от которого во многом зависело благополучие, да и сама жизнь человека.

У алтайцев был развит культ медведя. Это связано, скорее всего, с тем, что медведя - особо почитали как хозяина тайги, царя зверей (Ойношев, 2006: 89).

В алтайском языке согласно Н.А. Яимовой «наибольшим разнообразием эвфемизмов отличается название медведя, семантика которых указывает на особое почтительное отношение к этому зверю». Представители тубаларов слово айу (медведь) не употребляют, «... а говорят: абагай (дядя) или абышка (старик); если назвать медведя настоящим именем, он услышит, потому что медведь јеркулакту» (букв. слышащий через землю) (Яимова, 1990: 91). У алтайцев в качестве эвфемизмов, заменяющих слово айу, употреблялись следующие слова:

1) абаай /брат деда/, /дедушка/; 2) таай /дядя по матери/, /родственник по матери/; 3) таайёбёён /дядя по матери/; 4) таадак /дедушка по матери/; 5) карындаш /младший единоутробный брат/; 6) аба /старший родственник/; 7) тайганынг абазы /старший родственник, живущий в тайге/ 8) ёрёкён /почтительное отношение к старшим/9) мајаалай, мајалай, манјалай / медведь самец (Яимова, 1990: 94). Быть может, эти названия медведя отражают не только реальные, сколько мифологизированные связи в сочетании человек медведь. В древнетюркском языке, у хакасов (сагайцев и койбалов), бурят и монголов понятия «медведь» и «отец» обозначались одним и тем же термином aba (Илимбетова, 2012: 282). Эвфемизмы в названии медведя использовались для того, чтобы медведь не понял, что о нем говорят, и не рассердился.

В одном мифе, записанном В.И. Вербицким, рассказывается, что медведь был в прошлом человеком. Он «был силен, но простоват, и при этом ел так много, что семья оговаривала его. Однажды, рассердившись на упреки семьи, он отправился с веревкой в лес за дровами, но домой больше не возвращался, а превратился в зверя» (Вербицкий, 1893: 137). Вариант предания о превращении человека в медведя, встречается чаще, чем другие варианты. Так, образ мужчины, обидевшегося на свою семью и ушедшего в лес, в основном бытует у тубаларов. С.С. Суразаков пишет: «Звери и птицы почитались в качестве тотемов конкретных родов: айу /медведы/ был тотемом рода комдош (Суразаков, 1975: 212). Представление алтайцев о родстве с медведем, наверное, укрепляло внешнее сходство медведя с телом человека.

Медведь считается человеком и старшим братом не только у алтайцев, но и у многих тюрко-монголоязычных народов, у киргизов (Абрамзон, 1946: 126); чувашей (Салмин, 2010: 218); хакасов (Бурнакова, 2005: 219); тувинцев (Дьяконова, 2004: 113) и т.д. В «Указателе персонажей алтайской мифологии» зафиксировано, что медведь - покровитель шамана: спас его во время сожжения камов. Он делал отверстие на стене горящего жилища, выводил из огня шаманов (Ямаева, 2007: 97).

В записанных нами во время полевых экспедиций текстах, медведя считают умным, сильным животным. «Айу» медведя сотворил Эрлик-Бий, а палец отрезал ему Кудайза за то, что тот начал все вокруг ломать. Отрезанный палец Кудай отдал человеку, поэтому люди его называют братом. А в другой записи «Айуакабыс» говорится, что медведя сотворил Кудай. Сюжет в обоих текстах одинаков, исключая некоторые детали. Так же Кудай, отрезав большой палец, отдает человеку. Таким образом, Кудай уменьшил ум и силу медведя, которые находились в большом пальце. Поэтому человек, взявший палец 
медведя, называет его братом и старается не убивать его. Если все-таки приходится убить медведя, то стараются разубедить медведя, нашептывая ему на ушко, что он сам умер нечаянно, так как человек боится и не хочет отвечать за свой поступок на том свете. В тексте, записанном в Онгудайском районе «Айу» говорится, что медведь был человеком. Поссорившись с домочадцами, ушел в лес, заблудился, так и остался в лесу, весь оброс шерстью и стал медведем. Убеждение о том, что медведь был человеком, проявляется в охотничьих обрядах и суевериях. Когда убивают медведя, охотники совершают соответствующие обряды, придерживаются запретов. В исследованиях В.А. Муйтуевой отмечено, что на охоте охотники не называют вслух свои личные имена. На ухо убитого медведя шепотом говорят: «не говорите на том свете, что мы убили Вас, а скажите, что упали с дерева и умерли или упали со скалы и умерли, или - съели много ореха» (Муйтуева, 2004: 136). Тубалары, убив медведя, голову прячут. Такой же обряд был у хакасов; голову отрезали и, выбив зубы, прятали (Бутанаев, 1990: 41). Цель этих обрядов заключается в том, чтобы медведь на том свете не узнал убившего охотника. Магические свойства приписывались отдельным частям тела убитого зверя, оберегающим от несчастий и способствующим выздоровлению людей от болезни (Яимова, 1990: 90). Медвежьи когти могли огородить от злых духов, поэтому когти привязывали к колыбели ребенка, чтобы злые духи не приближались к ребенку. В качестве амулета, оберегающего от болезней, носили зубы медведя; больную голову очерчивали медвежьим когтем (Потапов, 1928: 18). Магический характер носил обычай принесения клятвы, когда «клянущийся садится на шкуру медведя и целует его ноздри. Медведь считается карателем за преступления...» (Потанин, 1883: 39). При всем обилии информации об обрядах, связанных с добычей медведя, фольклорных текстов, специальных работ о культе медведя у алтайцев немного, а исследований о современном бытовании медвежьей обрядности практически нет.

Интересны алтайские сказки о медведе («Страшный гость», «Медведь и хитрая лиса», «Пять братьев», «О медведе», «Медведь и птица» «О ласке Токтонок», «Медведь и кедровка», «Медведь и заяц» и т.д.) (Кучияк, Гарф, 1948: 75-85). Где медведь - это образ Хозяина Алтая, самого сильного, старшего и уважаемого зверя. В сказках медведь отличается от других зверей своим простодушием и доверчивостью. Этим особенно пользуется лиса. Он верит в зверей, но те его подлым образом обманывают. Так кедровка, войдя в доверие к медведю, утащила все шишки, лиса его столкнула со скалы и т.д. Медведь в мифах и сказках наделяется человеческой речью, способностью мыслить (Ӧзӧказиячӧрчӧктӧри, 2015: 116-125). В сказках через животных показываются действия людей, приписываемые животным, высмеиваются человеческие пороки, отражаются бытовые реалии.

В томе «Несказочная проза алтайцев» серии «Памятники фольклора народов Сибири и Дальнего Востока» есть предание под номером 46 «Медведь», где отмечено, что медведь раньше был человеком. Поссорившись с братом, одев наизнанку шубу, стал медведем. Но, когда на пасеке весь мед съел, люди его наказали за это: «Шесть месяцев пищу не ешь» (Несказочная проза алтайцев, 2011: 159). С тех пор медведь не ест шесть месяцев зимой. В 47 тексте в этом же томе - «Когда медведь жену (одного) человека унес», рассказывается, как медведь унес жену человека, и как эта женщина тоже обросла шерстью и стала есть сырое мясо. Но когда люди нашли ее и забрали, она пела - 
«Медведь, медведь, медведь,

Хоть и медведь, муж мой,

Берлога, берлога, берлога,

Хоть и берлога, дом мой, ...» (Несказочная проза алтайцев, 2011: 159).

В героических сказаниях медведь является Хозяином Алтая, в сказании «Кан-Капчыкай» золотошерстный медведь был охранником богатыря.

Таким образом, медведь в алтайском фрольклоре в основном выполняет положительную функцию. Перед нами образ сильного, справедливого, хозяйственного, в то же время чересчур доверчивого зверя, которого легко обмануть, то есть, создана полноценная человеческая натура со всеми ее противоречиями. Медведь - символ добродушия и ярости, богатырской силы и неуклюжести. Медведь выступает как тотемное животное у рода комдош, каратёёлёс, саал (Ямаева, 2007: 84). Почитание медведя выражается, прежде всего, в том, что алтайцы называют его не настоящим именем, а почтительно по-родственному акабыс, абагайи т.д. В сказках, мифрах, преданиях, героических сказаниях медведь считается хозяином Алтая.

По представлениям и обрядам алтайцев, связанным с медведем, у алтайцев существовал в далеком прошлом культ медведя. Образ медведя в устном народном творчестве алтайцев имеет и положительную и отрицательную характеристику.

По мнению некоторых исследователей, алтайцы почитают волка так же, как и собаку. В материалах А.В. Анохина особое отношение к волку показано в поверьях: «Когда волк воет, алтайцы говорят: волк у Кудая просит пищу. Волк давит скотину только тогда, когда на это будет согласие Кудая» (Анохин, 1924: 126). «Волк в мировоззрении алтайцев был тоже собакой» (Муйтуева, 2004: 89).

В алтайской сказке «Ийтлебӧрӱ» рассказывается о том, как одна собака превратилась в волка. В этой сказке человек по имени Кончыбай встретился с Дьелбегеном. Дьелбеген его хотел съесть, но он со своей семьей убежал в другое место. Сын Кончыбая второпях забыл свое ружье и решил вернуться за ним. Мальчик вернулся, а там Дьелбеген, так он начал преследовать сына Кончыбая. Мальчик залез на высокое дерево, Дьелбеген начинает рубить его. Прилетает сорока, мальчик просит позвать на помощь его собак. Сорока отказывается. Мимо пробегает лиса и обещает помочь Дьелбегену, говоря ему: «Иди, отдохни, дай свой топор, я буду рубить дерево». Когда Дьелбеген засыпает, лиса, замазав ему глаза глиной и выбросив топор в озеро, убегает. Дьелбеген просыпается, находит топор и продолжает рубить дерево. Мальчик просит синицу позвать на помощь его собак. Синица зовет на помощь собак. Собаки побеждают Дьелбегена, и убивают его. В бою одна собака получает раны и не может идти. Мальчик, обещав вернутся за ней, оставляет раненую собаку. Вернувшись домой, отдохнув, играя, забывает о раненой собаке. Собака долго ждет мальчика, превращается в волка и обещает нападать на скот людей (Алтайские народные сказки, 1972: 31-34), (Кучияк, 1948: 90-94). Таким образом, собака превратилась в волка.

Наши инфрорманты Петек Эчишевич Ойношев и Мария Михайловна Манзырова рассказали аналогичные предания о появлении волка. Аналогичный сюжет, только мальчика зовут Карабаш. Собаки приходят на помощь мальчику, но одна собака получает раны и остается в пути. За ним никто не приходит, он становится волком.

Преданий и мифов о том, что волчица является праматерью тюрков множество. Волк особо почитался как тотемный предок у рода Ашина. 
Согласно этому мифу, предки тюрков, составляли отдельный род хуннов и обитали на берегу западного моря. Эта ветвь была уничтожена соседним владетелем. В живых остался только десятилетний мальчик. Его не стали убивать из-за малолетства, но отрубили руки, ноги и бросили в травянистое озеро. Мальчика нашла волчица и стала кормить мясом. Узнав об этом, враги решили убить мальчика и волчицу. Но, волчица скрылась вместе с мальчиком в Алтайских горах. Так, волчица родила от мальчика десятерых сыновей. В числе сыновей волчицы был и Ашина, что означает «благородный волк». Ашина - прародитель тюрков, легендарный предок знаменитого в тюркомонгольском мире рода Ашина, с которым были связаны родословные ханских династий древних тюрков, голубых тюрков, хазар, монголов и т.д. (Гумилев, 2007: 25). Он был признан государем и в память о своем происхождении от волчицы на своих воротах вывешивал знамя с золотой волчьей головой (Бичурин, 1950: 221). Когда род Ашины сошел с арены, его тотем перестал иметь высокий статус. Похожий сюжет есть в преданиях гуннов. Когда гунны были истреблены соседями, остался лишь девятилетний мальчик. Ему, также отрубили руки и ноги и бросили в болото. Ему помогала волчица, которая от него забеременела. Когда мальчика убили, волчица убежала на Алтай и родила там сыновей (Гумилев, 2002: 175). С данными сюжетами перекликаются алтайские мифы о волчице. Предок кыпчаков стал жить с волчицей; волчица родила пятнадцать сыновей, ставших родоночальниками кыпчаков (Ямаева, 2007: 83).

В алтайских героических эпосах сохранились следы почитания волка. Например, в героическом сказании «Курман-Таајы», Хозяин Алтая фригурирует в образе белого волка. Белый волк говорит, что он раньше был Хозяином Алтая и был бессмертен, но когда постарел и получил раны, то превратился в синего волка.

«Мен алтайдын ээзиболгом,

«Я был хозяином Алтая,

Ӧлӧртынымјокболгон.

Эмди мен акбӧрӱэмес,

Албатынын малынјийтен

Я был бессмертен.

Теперь я не белый волк,

Кӧкбӧрӱболорым».

Скотину народа давящим

Синим волком буду» (Алтай

баатырлар, 1959: 61).

В героических сказаниях волки обычно являются противниками главных героев. Например, в сказании «ӦскӱсУул», «Ӧлӧштӧй», волк приходит, чтобы уничтожить богатырских коней. В героическом сказании «Ак Тайчы» белый волк с шестисаженным хвостом отбирает новорожденного сына богатыря АкБӧкӧ (Алтай баатырлар, 1959: 72). Волк воспитывает мальчика в пещере. Белый волк приводит мальчику-богатырю коня со всем снаряжением и дает ему имя Ак-Тайчы. Когда Ак-Тайчы вырос, белый волк рассказывает о его настоящих родителях, он забрал мальчика, чтобы Эрлик-бий не смог его забрать, как предыдущих двух братьев. Выехав из пещеры, Ак-Тайчы уничтожает подземных шулмусов Эрлика и наказывает его самого. Так, белый волк спас от смерти Ак-Тайчы, вырастил и воспитал богатыря.

В сказании «ӦскӱсУул» коня ӦскӱсУула крадет синий волк. ӦскӱсУул, идя по волчьему следу, попадает в пещеру, где живут отец, мать и дочь в облике волков:

Бирсарыкӱчӱгеш

Ак-сарыэнебӧрӥ

Кӧк-јажыл ада бӧрӥ

1959: 284).
Один желтый щенок,

Бело-желтая волчица-мать,

Сине-зеленый волк-отец (Алтай баатырлар, 
В пещере они оказались из-за того, что, богачи хотели отобрать единственную дочь. Так, ӦскӱсУул женился на их дочери, приобрел счастье и богатство. В данном героическом сказании семья оказывается превращенной в волков из-за обстоятельств тяжелой судьбы.

В героическом эпосе «Ак-Бий» герою помогает жениться «хозяин тайги» Белый волк (Суразаков, 1958: 72). Белый волк в алтайских героических сказаниях является главным покровителем богатырей. Белый волк во всех сказаниях является положительным героем. В татарской сказке «Белый волк» - это мудрый, справедливый, идущий на помощь в трудную минуту зверь. У хакасов в героическом эпосе «Албынжи» белый волк является помощником героя, который заменяет ему коня (Героический эпос, 1957: 461).

Согласно Н.В. Екееву культ волка архаичный, существовал у ряда древних и средневековых народов Евразии. В тюрко-телеских легендах образ волчицы (волка), вероятно, был, прежде всего, связан с культом Неба, а через сакральную горную «пещеру предков» - с культом Земли. ... На примере алтайского эпоса можно сказать, что в этот период появляются разные цветовые обозначения волка, связанные с определенными культами: синий волк - с Небом; белый волк - со светлыми земными божествами, духом «хозяином» Алтая; желтый волк - с культом Матери-Земли; черный волк - это воплощение сил зла или «нижнего» (подземного) мира» (Екеев, 2014: 30).

Исследователи А.Ф. Илимбетова и Ф.Ф. Илимбетов отмечают, что волк как тотем, «тотемный предок, патрон и божество был у башкир табуированным зверем. Его рудименты обнаруживаются в запрете называть волка настоящим именем, убивать волчат, употреблять в пищу мясо, самовольно вторгаться в освоенную им территорию, за нарушение которых виновнику грозило "сверхъестественное» (волчье) наказание, болезнь или смерть» (Илимбетова, 2012: 115). В мифах чувашей волчица представляется как прародительница, как кормилица и воспитательница их первопредка (Культура чувашского края, 1995: 129). Племена, которые считали своим прародителем волка, есть и у монголов.

Таким образом, в героических сказаниях алтайцев белый волк воспитатель младенцев, помощник богатыря. Белый волк - Хозяин Алтая. У древних тюрков был широко распространен культ волка, однако у алтайцев он почти не сохранился. По преданиям и сказкам волк - это одичавшая собака, черный волк - это воплощение сил зла или «нижнего» (подземного) мира.

В мире, где обитают сурки, среди населения ходит много легенд и преданий. Их любят за мирный характер, трудолюбие, коллективный образ жизни. У алтайцев, как и у монголов, существует много преданий о сурке.

В алтайских преданиях, легендах о сурке говорится, что сурок раньше был человеком, метким стрелком. Отчего у сурка пальцы похожи на человеческие, но нет большого пальца? Во всех вариантах говорится о том, что у сурка нет большого (эргексабар) пальца. В преданиях говорится о том, как он лишился большого пальца из-за того, что не попал в птицу, он сам отрубил себе палец. Если в записях у Г.Н. Потанина палец сурку отрубил Кан Гередей (мифологическая птица) (Потанин, 2005: 180), то в одной нашей записи это сделал Кудай, во всех других вариантах преданий о сурке палец отрубил он сам из-за того, что неточно выстрелил в коршуна (телеген) или просто в птицу. Мифическая птица Кан-Кереде в устном народном творчестве алтайцев встречается часто.

В томе «Несказочная проза алтайцев» серии «Памятники фрольклора народов Сибири и Дальнего Востока» есть текст под номером 44 «Тарбаган». В 
данном тексте говорится, что сурок прежде был прославившимся охотником, работящим, трудолюбивым человеком. Сюжет такой же, как и во многих других версиях о сурке один палец от стыда сам себе торопливо отрезал и прыгнул под землю (Несказочная проза алтайцев, 2011: 154-155).

В записях у И.Б. Шинжина (Алтай кеп-куучындар, 1994: 354) в предании «Тарбаган» охотник по имени Тарбаган поспорил (кто стреляет без промаха) с юношей по имени Телеген. Когда Телеген высоко взлетит, Тарбаган должен стрелять из ружья. Но Тарбаган промахнулся, пуля прошла, задев хвост Телегена. В данном тексте Тарбаган стрелял из ружья, а парящей в небе птицей был юноша по имени Телеген. В конце так же, как и во всех других вариантах, Тарбаган, отрубив себе большой палец, уходит под землю (Алтай кеп-куучындар, 1994: 354). В книге «Мифы и легенды» (Мифы и легенды, 2007: 25-26) под номером 16 есть легенда «Тарбаган». Как и в других вариантах, говорится о том, что сурок раньше был человеком. Но в данном тексте сурок стрелял в коршуна, когда тот пролетел через отверстие - дымоход (тӱнӱк) в юрте, но промахнулся, стрела прошла, разорвав хвост коршуна. В тексте так же говорится, что сурка невозможно застрелить, его только силком ловят, так как он умен, как человек. И нору свою строит основательно, замазывая снаружи глиной и делая водостоки.

В исследованиях К.В. Ядановой (Яданова, 2013: 170) есть два варианта предания о сурке: первый - «Сурок был человеком», и второй «Стрелок Тарбаан». Сюжет во всех преданиях одинаков, выстрел стрелка в птицу. Во втором варианте предания говорится, что у сурка и ключица, и лопатка как у человека. В наших записях нет упоминаний о ключице тарбагана. В других фрольклорных материалах записи о ключице мы тоже не встретили.

Таким образом, во всех вариантах предания «О сурке» человек, который был очень метким стрелком, не попав в летящую птицу, отрубил себе палец, превратился от стыда в тарбагана и ушел под землю. В одной версии сурок был богатырем, у которого стрела никогда на землю не падала. Для алтайцев сурок является культовым животным. Те охотники, которым удалось видеть нору сурка, говорят, что он его строит основательно из нескольких помещений, лепит нору из глины, чтобы дождевая вода не попадала вовнутрь норы, рядом с домом делает дренаж для воды.

Во всех найденных нами материалах говорится, что сурок раньше был человеком-стрелком, и у него нет большого пальца. Днем сурок обычно не выходит, не показывается людям, старается выходить ночью, всегда кричит: (уйаттузын, уйаттузын!) «стыдно, стыдно!». В одном тексте говорится, что у сурка лопатка похожа на человеческую лопатку. В другой версии говорится, что в подмышках у сурка есть белое мясо, которое нельзя есть, оно похоже на человечье. В алтайской сказке «Энирјылдыс ла Тарбаган» сурок не попал в вечернюю звезду, так как стрелял он ночью, завязав глаза, и поэтому прыгнул от стыда под землю, и днем стесняется показываться людям. В сказке показано, что народ очень уважал сурка, он всегда делился добычей со своим народом (Акулова, 2003: 173).

Предания о сурке широко распространены не только на Алтае, но и в Монголии. Алтайские предания о сурке объясняют происхождение сурка и почему у коршуна хвост рассечен. Ведь в него стрелял тарбаган, стрела (в некоторых текстах пуля) рассекла хвост коршуна на две части. С тех пор хвост коршуна рассечен на две части. В преданиях сравниваются сходство сурка и человека, потому что сурок, оказывается, раньше был человеком. 
Нам удалось записать несколько текстов преданий о барсуке, где говорится, что он - старательный хозяин. В двух текстах говорится о лекарственном действии барсучьего жира. В тексте «Борсуктынӱзи / Барсучий жир», информант Елтокова Екатерина в Усть-Канском районе рассказала нам, как однажды мужчина понял о лекарственном свойстве барсучьего жира. Когда у него сильно болел ребенок, никто не смог помочь. Ребенок умер. Осталась у мужчины кровь ребенка, которая обнаружилась в артерии, эта кровь была каменной. Он носил кровь своего ребенка как талисман на шее. Но однажды на охоте застрелил барсука, и, когда разделывал, талисман, задевая теплое сало барсука, растаял. Он удивился. Ведь никто не смог помочь его ребенку, ни шаманы, ни доктора, а барсучий жир без труда растопил застывшую кровь. После этого случая мужчина рассказал всему народу о барсучьем жире. С тех пор люди начали употреблять барсучье сало и мясо как лекарство. Аналогичный сюжет встречается у тувинцев (Сказки и предания, 1994: 382), где один мужчина узнал о целебном свойстве барсучьего жира. Появление этого мифа, по нашему мнению, скорее связано с целебными свойствами барсучьего жира.

В тексте, записанном от М.К. Ялаевой «Борсыктынэди, јуузыэмдӱ / Барсучье мясо, жир-лекарство», тоже говорится о лекарственном действии барсучьего жира. В данном тексте говорится, что можно с помощью барсучьего жира лечить легкие, сердце. Информант вспоминает, что им в детстве всегда при кашле давали барсучий жир. В доказательство она говорит: если на «свежее только разделанное сало попробуете положить струю свернувшейся крови, и минуты не пройдет, как она растает». В тексте, записанном в УстьКанском районе в селе Кайсын, Г.А. Муйтуева в отличие от двух предыдущих информантов объясняет, почему у барсука лоб белый, лысый и почему он живет под камнем, об этом же повествуется в алтайской сказке «Борсык» (Азия чӧрчӧктӧри, 2015: 131-134). В ней говорится, что когда-то барсук имел четырех братьев, был самым старшим из братьев и очень хвастливым. У алтайцев есть известное выражение: «Борсуккалјанынбодонбос» (букв. Барсук свою лысину не замечает) (Алтай чӱмдӱсӧс 2007: 34), это относится и к людям, которые чрезмерно хвастливы и не выполняют данных обещаний. В алтайских сказках «Борсык / Барсук», «Борсук ла Сыгын / Барсук и Марал», он так же характеризуется как очень хвастливое, но тем не менее, безобидное животное (Азиячӧрчӧктӧри 2015: 131-134; Чанкыртуулардынчӧрчӧктӧри 1993: 68-70), выходит только по ночам, всего боится и старается никому не показываться. То, что он выходит по ночам, в алтайских сказках объясняется тем, что он боится своих братьев. Он во многих сказках является старшим братом зверей, наверное, из-за хозяйственности «Борсык», «Борсук ла Сыгын» (Чанкыртуулардынчӧрчӧктӧри, 1993: 68; Азия чӧрчӧктӧри, 2015: 131; Алтынтонустынсыйы, 1975: 28). А белая залысина на голове барсука - это следы от копыт марала. Звери в мифах и сказках о животных ведут себя, как люди. Человек искренне верил, что присущие ему черты характерны и для животных.

Живет барсук в норе, барсучья нора - сложное инженерное сооружение с различными кладовками, тупиками и ответвлениями. По своей домовитости, хозяйственности и обстоятельности барсуки чем-то сродни с людьми. В алтайских сказках все звери-братья. Барсук любит строить свой дом с комфортом, чтобы его участок был рядом с рекой или ручьем. Летом и осенью он готовит запасы на весну и нагуливает жир, зимой спит. Для человека очень полезен барсучий жир и мясо. Традиционно используют барсучий жир для укрепления иммунитета, чтобы быстро справиться с простудой и кашлем, жир 
способствует заживлению ран и защищает кожу от обморожения и обветривания.

Одним из интересных животных по мировоззрению алтайцев является заяц. Алтайцы держат табу по отношению к нему (не охотятся, не едят мяса зайца). Заяц, по утверждению алтайцев, имеет небесное происхождение. В алтайских мифах повествуется, что дочери неба спустились на землю искупаться. Но, когда они купались, человек украл одежду одной дочери, тем самым осквернил ее. Оставшись на земле, девушка оборачивается зайцем, становится посредником / јайык /, охраняющим человека от всех несчастий и бед (Анохин, 1924: 12).

Јайык (семейное божество, посредник) у алтайцев пользуется особым уважением. В.А Муйтуева отмечает, если род мужчины имеет јайык омкойон / зайца, то он не имеет права охотиться на это животное, употреблять его мясо. Койон / заяц является почитаемым животным рода тодош, сойон, кӧбӧк и т. д. (Алтайцы, 2005: 176). Женщинам запрещается даже трогать и шить одежду из шкуры зайца (Муйтуева, 2004: 145).

В своих исследованиях Н.О. Тадышева пишет, что «... с возникновением бурханизма значение јайык`а актуализировалось и со временем он трансформировался в самостоятельное семейное божество. В настоящее время обрядовые действия јайык'у совершаются главным образом в семейном кругу - при каждом новолунии окропляют молоком, чаем, окуривают арчыном и выполняет ритуал хозяин дома. Так же два раза в год во время јажылбӥр (зеленая листва) и сарыбӱр (желтая листва) проводится обряд «јайыккӧдӱрер» (букв. поднимать, здесь обряд јайыку (восхваление)) во время новолуния, обязательно только в самые благоприятные дни - на четвертый или седьмой день новолуния. Для проведения обряда заранее готовят молоко, которое никто не пробовал, чай, арчын(можжевельник), арачку (молочная водка), боорсок (мучное изделие круглой формы, из пресного теста, жареное в масле). Обязательно обряд сопровождается благопожеланиями алкыш, просят благословения Алтаю, народу, семье. (Тадышева, 2015: 111).

Интересен образ зайца в алтайских сказках, где, как и в сказках у многих других народов, он отмечается своей непоследовательностью. В одних сказках, которые появились более позднее, «Койондор / Зайцы», он показан трусливым и беспомощным, это скорее заимствовано из русских сказок (Азия чӧрчӧктӧри, 2015: 117; Жемчужные сказки 2004: 18), в других, более ранних, он щедрый и добрый помощник зверей, хороший и справедливый зверь «Койонокло Айу / Заяц и медведь», «Агас ла Койон / Горностай и заяц», «Коркуштуайылчы / Страшный гость» (Алтай чӧрчӧктӧр, 1954: 27; Койонок, 1958: 3).

В основном это положительный герой. У алтайцев есть поверье: если на пути встретится заяц, то будет сопутствовать большая удача. Исследователи считают, что почитание зайца связано с солярным культом, (все белые животные считались символом солнца на земле). Видимо, культ зайца является довольно древним культом (Муйтуева, 2004: 146).

Заключение. Исследуя образы животного мира в устном народном творчестве алтайцев и их функции в пространственном мировоззренческом аспекте, мы приходим к выводу, что у всех животных есть строгое местоопределение, в соответствии с их фрункциональной характеристикой. В зависимости от соответствия с верхним или нижним миром, характеристика большинства животных приобретает или отрицательную, или положительную нагрузку. Но в то же время на основании анализа образов, мы считаем, что 
художественные образы не всех животных воспринимаются однозначно, в плане соотнесения их к верхнему или нижнему миру. Есть некоторые образы, которые сохраняют нейтральную функциональную нагрузку, а некоторые, как например, медведь или волк, в одних несут отрицательную, а в других положительную нагрузку. Животные, созданные Верхним божеством, относятся к Верхнему, положительному миру. Животные, созданные Нижним божеством, относятся к Нижнему, отрицательному миру. Исследование устного народного творчества показывает, что при создании образов животного мира народ, прежде всего, опирался на дуальную мировоззренческую структуру пространства. Мир упорядочен. Конечно, образ каждого животного вбирал различные разновременные влияния, но их функциональная сущность опирается на их соотнесенности к полюсам мира.

Таким образом, можно сделать следующие выводы:

- в устном народном творчестве алтайцев сохранились тотемические представления (происхождение отдельных родов от животных), т.е. животные выступают как мифические прародители (кормильцы) предков алтайцев;

- сформированы представления о некоторых сверхъестественных способностях животных, оказывающих благотворное влияние на жизнь людей;

- различные части тела или предметы, с которыми животные соприкасаются, сакрализуются и выступают в суевериях и поверьях алтайцев как обереги или охранители жизни и здоровья, покровители в трудных ситуациях;

- в отношении всех животных соблюдались определенные ограничения табу. Табуированием в словах и действиях люди старались не рассердить, расположить их в свою пользу, нейтрализовать отрицательные последствия.

\section{Әдебиеттертізімі / Список литературы}

1. Абрамзон, 1971 - Абрамзон С.М. Киргизы и их этногенетические и историко-культурные связи. Л., 1971.

2. Азия чӧрчӧктӧри (Сказки народов Центральной Азии). 2 том. / Горно-Алтайск, 2015, 436 с. на алт. яз.

3. Акулова, 2003 - Акулова Т.Н. Чарас - колыбель сказок. Благопожелания, сказки. ГорноАлтайск, 2003.

4. Алтай албатынын чӧрчӧктӧри (Алтайские народные сказки). Горно-Алтайск, 1966. - 64 с.

5. Алтай баатырлар (Алтайские богатыри.Алтайский героический эпос) / Сост. С. Суразаков, T.II. Горно-Алтайск, 1959. - С. 68-306.

6. Алтай баатырлар (Алтайские богатыри.Алтайский героический эпос) / Сост. С. Суразаков, Т. III. Горно-Алтайск, 1960. - С. 296-324.

7. Алтай баатырлар (Алтайские богатыри.Алтайский героический эпос) / Сост. С. Суразаков, T. VII. Горно-Алтайск, 1972. - C.56-78.

8. Алтай баатырлар (Алтайские героические сказания) / Сост. А.А. Конунов. Горно-Алтайск: ОАО «Горно-Алтайская типография», 2013. - 438 с.

9. Алтай кеп-куучындар (Алтайские легенды, предания). / Сост. Е.Е. Ямаева, М.Б. Шинжин. Горно-Алтайск, 1994. - 416 с. на алт.яз.

10. Алтай чӱмдӱсӧс (Крылатые слова). / Сост. К. Петешева. Горно-Алтайск, 2007.

11. Алтайские сказки. Горно-Алтайск, 1996. - 208 с.

12. Алтайские сказки. Горно-Алтайск, 2009. - 279 с.

13. Алтайские сказки. Новосибирск, 1952. - 72 с.

14. Алтайцы (Материалы по этнической истории) / Сост. Екеев Н.В. Горно-Алтайск, 2005, 176 с.

15. Аносский сборник; репринт..изд. / Сост. Н.Я. Никифоров. Горно-Алтайск: Ак Чечек, 1995. - 264 с.

16. Анохин, 1924 - Анохин А.В. Материалы по шаманству у алтайцев, собранные во время путешествий по Алтаю 1910-1912 гг. по поручению Русского комитета для изучения Средней и Восточной Азии // Сборник Музея антропологии и этнографии, т. IV, вып. 2. Л., 1924. - С.152.

17. Баскаков, 1975 - Баскаков Н.А. Пережитки табу и тотемизма в языках народов Алтая // Советская тюркология, 1975. № 2. - С 8. 
18. Бичурин, 1950 - Бичурин Н.Я. Собрание сведений о народах, обитавших в Средней Азии в древние времена. Т. І. М.; Л., 1950. - С. 221.

19. Бутанаев, 1990 - Бутанаев В.Я. Медвежий праздник у хакасов // Традиционное мировоззрение народов Сибири и сопредельных территорий (Тезисы и материалы докладов и сообщений Всесоюзной научной конференции). Улан-Удэ, 1990.

20. Вербицкий, 1893 - Вербицкий В.И. Алтайские инородцы. М. 1893. - 386 с.

21. Гумилев, 1993 - Гумилев Л.Н. Древние тюрки. М., 1993.

22. Екеев, 2014 - Екеев Н.В. Об образе волка/волчицы и «пещере предков» древних тюрков // Урал - Алтай: через века в будущее. Материалы Всероссийской научной конференции / БНУ РА «Научно-исследовательский институт алтаистики им С.С. Суразакова». Горно-Алтайск: ОАО «Горно-Алтайская типография», 2014.

23. Екеев, 2010 - Екеев Н.В. Охота и собирательство // История Республики Алтай. Т. 2. ГорноАлтайск, 2010. - С. 140-143.

24. Жемчужные сказки: Сказки народов мира. Горно-Алтайск, 2004. - 456 с.

25. Илимбетова, 2012 - Илимбетова А.Ф., Илимбетов, Ф.Ф. Культ животных в мифоритуальной традиции башкир. 2-е изд., испр. и доп. Уфа: АН РБ, Гилем, 2012, 704 с.

26. Койонок / Сост. И. Шодоев. Горно-Алтайск, 1958.

27. Культура чувашского края. Чебоксары, 1995.

28. Липец, 1981 - Липец Р.С. Лицо волка благословенно... (стадиальные изменения образа волка в тюрко-монгольском эпосе и генеалогических сказаниях) // Советская этнография, № 1. 1981. - С. $120-133$.

29. Мифы и легенды / Отв. ред. Демчинова М.А. Горно-Алтайск: Институт алтаистики им. С.С. Суразакова, 2007.

30. Муйтуева, 2004 - Муйтуева В.А. Традиционная религиозно-мифологическая картина мира алтайцев: Монография. Горно-Алтайск: Типография ЧП Высоцкого Г.Г., 2004. - 166 с.

31. Муйтуева, Чочкина, 1996 - Муйтуева В.А., Чочкина М.П. Алтай јан (Алтайские обычаи). / В.А. Муйтуева, М.П. Чочкина. Горно-Алтайск, 1996. - 208 с.

32. Муйтуева, 2015 - Муйтуева И.Н. Тарбаган в несказочной прозе алтайцев. // СевероВосточный гуманитарный вестник. № 2, 2015. - С. 75-81.

33. Несказочная проза алтайцев / Сост. Н.Р. Ойноткинова, И.Б. Шинжин, К.В. Яданова, Е.Е. Ямаева. Новосибирск: Наука, 2011. - 576 с.

34. Ӧзӧказиячӧрчӧктӧри / Сказки народов Центральной Азии, 2-й том / Сост. С.С. Торбоков. Горно-Алтайск, 2015. - С. 109-157.

35. Ойношев, 2006 - Ойношев В.П. Система мифологических символов в алтайском героическом эпосе. Горно-Алтайск, 2006. - 164 с.

36. Потанин, 1883 - Потанин Г.Н. Очерки Северо-Западной Монголии. Вып. IV. СПб., 1883. - 1025 с.

37. Пропп, 1986 - Пропп В. Я. Исторические корни волшебной сказки. Л., 1986. - 365 с.

38. Сагалаев, 1984 - Сагалаев А. М. Мифология и верования алтайцев: Центральноазиатские влияния. Новосибирск: Наука, 1984. - 120 с.

39. Салмин, 2010 - Салмин А.К. Традиционные обряды и верования чувашей. СПб., 2010. - С. 218.

40. Сказки и предания алтайских тувинцев. М., 1994. - 382 с.

41. Суразаков, 2015 - Суразаков С.С. Алтай фольклор (Алтайский фольклор). 2-е издание, дополненное / БНУ РА «НИИ алтаистики им С.С. Суразакова»; ред. А.А. Конунов. Горно-Алтайск, 2015. - С. 123-147. на алт.яз.

42. Суразаков, 1958 - Суразаков С.С. Героический эпос алтайцев // Ученые записки.вып. 2. Горно-Алтайск, 1958. - С. 72.

43. Тадышева, 2015 - Тадышева Н.О. Символы и знаки в традиционной алтайской культуре: обмен дарами // Идель - Алтай: история и традиционная культура народов Евразии. Материалы III Международного фрорума, посвященного 90-летию доктора филологических наук, профессора С.С. Суразакова / БНУ РА «НИИ алтаистики им С.С. Суразакова». Горно-Алтайск: ООО «ГорноАлтайская типография», 2015. - С.110-112.

44. Яданова, 2013 - Яданова К.В. Предания, легенды, былички теленгитов долины Эре-Чуй. Горно-Алтайск, 2013. - 256 с.

45. Яданова, 2013 - Яданова К.В. Указатель сюжетов и версий по материалам алтайской фольклорной традиции: «Встреча охотника с мифическим существом». Горно-Алтайск, 2013. - 288 с. 46. Яимова, 1990 - Яимова Н.А. Табуированная лексика и эвфемизмы в алтайском языке. Горно-Алтайск, 1990, 169 с.

47. Ямаева, 2007 - Ямаева Е.Е. Указатель персонажей алтайской мифологии. Горно-Алтайск, 2007. -58 c. 


\section{References}

Abramzon, 1971 - Abramzon S.M. Kirgizyi i hetnogeneticheskie i istoriko-kul'turnye svyazi.L., 1971. [In Rus.]

Aziya chörchöktöri (Skazki narodov Central'noj Azii). 2 tom. / Gorno-Altajsk, 2015, 436 s. na alt. yaz.

Akulova, 2003 - Akulova T.N. CHaras - kolybel' skazok. Blagopozhelaniya, skazki. Gorno-Altajsk, 2003. [In Rus.]

Altaj albatynyн chörchöktöri (Altajskie narodnye skazki).Gorno-Altajsk, 1966. - 64 s. [In Rus.]

Altaj baatyrlar (Altajskie bogatyri. Altajskij geroicheskij epos) / Sost. S. Surazakov, T.II. Gorno-Altajsk, 1959. - S. 68-306.

Altaj baatyrlar (Altajskie bogatyri. Altajskij geroicheskij epos) / Sost. S. Surazakov, T. III. Gorno-Altajsk, 1960. - S. 296-324. [In Rus.]

Altaj baatyrlar (Altajskie bogatyri. Altajskij geroicheskij epos) / Sost. S. Surazakov, T. VII. Gorno-Altajsk, 1972. - S.56-78. [In Rus.]

Altaj baatyrlar (Altajskie geroicheskie skazaniya) / Sost. A.A. Konunov. Gorno-Altajsk: OAO «GornoAltajskaya tipografiya», 2013. - 438 s. [In Rus.]

Altajkep-kuuchyndar (Altajskie legendy, predaniya). / Sost. E.E. YAmaeva, M.B. SHinzhin. GornoAltajsk, 1994. - 416 s. naalt.yaz.

Altaj chÿmdÿsös (Krylatyeslova). / Sost. K. Petesheva. Gorno-Altajsk, 2007.[In Rus.]

Altajskie skazki. Gorno-Altajsk, 1996. - 208 s. [In Rus.]

Altajskie skazki. Gorno-Altajsk, 2009. - 279 s. [In Rus.]

Altajskie skazki. Novosibirsk, 1952. - 72 s. [In Rus.]

Altajcy (Materialypo etnicheskoj istorii) / Sost.Ekeev N.V. Gorno-Altajsk, 2005. - 176 s. [In Rus.]

Anosskij sbornik; reprint..izd. / Sost. N.YA. Nikiforov. Gorno-Altajsk: AkCHechek, 1995. - 264 s. [In Rus.]

Anohin, 1924 - Anohin A.V. Materialy po shamanstvu u altajcev, sobrannye vo vremya puteshestvij po Altayu 1910-1912 gg. Po porucheniyu Russkogo komiteta dlya izucheniya Sredneji Vostochnoj Azii // Sbornik Muzeya antropologii i etnografii, t. IV, vyp. 2. L., 1924. [In Rus.]

Baskakov, 1975 - Baskakov N.A. Perezhitki tabu i totemizma v yazykah narodov Altaya // Sovetskaya tyurkologiya, 1975. № 2. [In Rus.]

Bichurin, 1950 - Bichurin N.YA. Sobranie svedenij o narodah, obitavshih v Srednej Azii v drevnie vremena.T. I. M.; L., 1950. [In Rus.]

Butanaev, 1990 - Butanaev V.YA. Medvezhij prazdnik u hakasov // Tradicionnoe mirovozzrenie narodov Sibiri i sopredel'nyh territorij (Tezisy i materialy dokladov i soobshchenij Vsesoyuznoj nauchnoj konferencii). Ulan-Ude, 1990. [In Rus.]

Verbickij, 1893 - Verbickij V.I. Altajskiei norodcy. M. 1893. - 386 s. [In Rus.]

Gumilev, 1993 -Gumilev L.N. Drevnie tyurki.M., 1993. [In Rus.]

Ekeev, 2014 - Ekeev N.V. Ob obrazevolka/volchicyi "peshcherepredkov» drevnihtyurkov // Ural-Altaj: cherezveka $v$ budushchee. MaterialyVserossijskojnauchnojkonferencii / BNU RA «Nauchno-issledovatel'skijinstitutaltaistikiim S.S. Surazakova».Gorno-Altajsk: OAO «GornoAltajskayatipografiya», 2014. [In Rus.]

Ekeev, 2010 - Ekeev N.V. Ohota i sobiratel'stvo // Istoriya Respubliki Altaj. T. 2. Gorno-Altajsk, 2010. [In Rus.]

ZHemchuzhnye skazki: Skazki narodov mira. Gorno-Altajsk, 2004. - 456 s. [In Rus.]

llimbetova, 2012 - llimbetova A.F., llimbetov, F.F. Kul't zhivotnyh v miforitual'noj tradicii bashkir. 2-e izd.,ispr. idop. Ufa: AN RB, Gilem, 2012. - 704 s. [In Rus.]

Kojonok / Sost. I. SHodoev. Gorno-Altajsk, 1958. [In Rus.]

Kul'tura chuvashskogo kraya. CHeboksary, 1995. [In Rus.]

Lipec, 1981 - Lipec R.S. Lico volka blagoslovenno... (stadial'nye izmeneniya obraza volka v tyurko-mongol'sko meposei genealogicheskih skazaniyah) // Sovetskaya etnografiya, № 1. 1981. - S. 120-133. [In Rus.]

Mifyilegendy / Otv.red. Demchinova M.A. Gorno-Altajsk: Institut altaistikiim. S.S. Surazakova, 2007. [In Rus.]

Mujtueva, 2004 - Mujtueva V.A. Tradicionnaya religiozno-mifologicheskaya kartina mira altajcev: Monografiya. Gorno-Altajsk: Tipografiya CHP Vysockogo G.G., 2004. - 166 s. [In Rus.]

Mujtueva, CHochkina, 1996 - Mujtueva V.A., CHochkina M.P. Altajjar (Altajskie obychai). / V.A. Mujtueva, M.P. CHochkina. Gorno-Altajsk, 1996. - 208 s. [In Rus.]

Mujtueva, 2015 - Mujtueva I.N. Tarbagan v neskazochnoj proze altajcev. // Severo-Vostochnyj gumanitarnyj vestnik. № 2, 2015. - S. 75-81. [In Rus.]

Neskazochnaya proza altajcev / Sost. N.R. Ojnotkinova, I.B. SHinzhin, K.V. YAdanova, E.E. YAmaeva. Novosibirsk: Nauka, 2011. - 576 s. [In Rus.]

Özökaziya chörchöktöri / Skazki narodov Central'noj Azii, 2-j tom / Sost. S.S. Torbokov. Gorno-Altajsk, 2015. - S. 109-157. [In Rus.]

Ojnoshev, 2006 - Ojnoshev V.P. Sistema mifologicheskih simvolov v altajskom geroicheskom 
epose.Gorno-Altajsk, 2006. - 164 s. [In Rus.]

Potanin, 1883 - Potanin G.N. Ocherki Severo-Zapadnoj Mongolii.Vyp. IV. SPb., 1883. - 1025 s. [In Rus.]

Propp, 1986 - Propp V. YA. Istoricheskie korni volshebnoj skazki. L., 1986. - 365 s. [In Rus.]

Sagalaev, 1984 - Sagalaev A. M. Mifologiya i verovaniya altajcev: Central'noaziatskie vliyaniya. Novosibirsk: Nauka, 1984. - 120 s. [In Rus.]

Salmin, 2010 - Salmin A.K. Tradicionnye obryady i verovaniya chuvashej. SPb., 2010. - S. 218. [In Rus.]

Skazkii predaniya altajskih tuvincev.M., 1994. - 382 s. [In Rus.]

Surazakov, 2015 - Surazakov S.S. Altaj fol'klor (Altajskij fol'klor).2-e izdanie, dopolnennoe / BNU RA «NII altaistikiim S.S. Surazakova»; red. A.A. Konunov. Gorno-Altajsk, 2015. - S. 123-147. naalt.yaz.

Surazakov, 1958 - Surazakov S.S. Geroicheskij epos altajcev // Uchenye zapiski.vyp. 2. Gorno-Altajsk, 1958. - S. 72. [In Rus.]

Tadysheva, 2015 - Tadysheva N.O. Simvolyiznaki v tradicionnoj altajskoj kul'ture: obmen darami // Idel' - Altaj: istoriya i tradicionnaya kul'tura narodov Evrazii. Materialy III Mezhdunarodnogo foruma, posvyashchennogo 90-letiyu doktora filologicheskih nauk, professora S.S. Surazakova / BNU RA «NII altaistikiim S.S. Surazakova». Gorno-Altajsk: OOO «Gorno-Altajskaya tipografiya», 2015. - S.110-112. [In Rus.]

YAdanova, 2013 - YAdanova K.V. Predaniya, legendy, bylichki telengitov doliny Ere-CHuj. GornoAltajsk, 2013. - 256 s. [In Rus.]

YAdanova, 2013 - YAdanova K.V. Ukazatel' syuzhetov i versij po materialam altajskoj fol'klor nojtradicii: «Vstrecha ohotnika s mificheskim sushchestvom». Gorno-Altajsk, 2013. - 288 s. [In Rus.]

YAimova, 1990 - YAimova N.A. Tabuirovannaya leksika i evfemizmy v altajskom yazyke.Gorno-Altajsk, 1990. - 169 s. [In Rus.]

YAmaeva, 2007 - YAmaeva E.E. Ukazatel' personazhej altajskoj mifologii.Gorno-Altajsk, 2007. 58 s. [In Rus.] 